\title{
Pangshura sylhetensis Jerdon 1870 - Assam Roofed Turtle
}

\author{
Indraneil Das ${ }^{1}$, Saibal Sengupta $^{2}$, and Peter Praschag ${ }^{3}$ \\ ${ }^{1}$ Institute of Biodiversity and Environmental Conservation, \\ Universiti Malaysia Sarawak, 94300 Kota Samarahan, Sarawak, Malaysia [idas@ibec.unimas.my]; \\ ${ }^{2}$ Department of Zoology, Arya Vidyapeeth College, Guwahati 781 016, Assam, India \\ [senguptasaibal@yahoo.co.in]; \\ ${ }^{3}$ Am Katzelbach 98, 8054 Graz,Austria [peter@praschag.at]
}

Summary. - The Assam roofed turtle, Pangshura sylhetensis (Family Geoemydidae), is a small freshwater turtle (straight carapace length [CL] only to $185 \mathrm{~mm}$ ), with thirteen pairs of marginals and a strikingly spiked vertebral keel. The species is strongly sexually dimorphic, with female CL to $185 \mathrm{~mm}$ and males to $97 \mathrm{~mm}$. It occurs primarily in running waters in the hills of northeastern India and northeastern and southeastern Bangladesh, where it appears rare and localized. Little information exists on the biology of this species. It apparently nests between late October and February, corresponding with the cool, dry season, and produces clutches of ca. 6-12 eggs, hatchlings appearing mainly between March and April, at the beginning of the Southeast Monsoons. The species is threatened by logging of primary forests that causes siltation, capture for food and the pet trade, and incidental capture in fishing gear.

Distribution. - Bangladesh, India. Localized distributed in northeast India and northeastern and southeastern Bangladesh.

Synonymy. - Pangshura sylhetensis Jerdon 1870, Jerdonella sylhetensis, Kachuga sylhetensis, Kachuga (Pangshura) sylhetensis.

SubSPECIES. - None recognized.

Status. - IUCN 2010 Red List: Endangered (B1+2c) (assessed 2000); CITES: Appendix II; Indian Wildlife (Protection) Act: Schedule I.

Taxonomy. - Pangshura sylhetensis was described by Jerdon in 1870 , based on three syntypes that were deposited in the British Museum (Natural History), from the Khasi Hills of Sylhet District (at present in Bangladesh). Subsequently, Gray (1870) transferred the taxon to a new monotypic genus,
Jerdonella, but Boulenger (1889) transferred it to the broad genus Kachuga. Moll $(1986,1987)$ revived Pangshura as a subgenus for this and several other small turtles that were still allocated to Kachuga. More recently, this species and its relatives have been reallocated to its original genus,

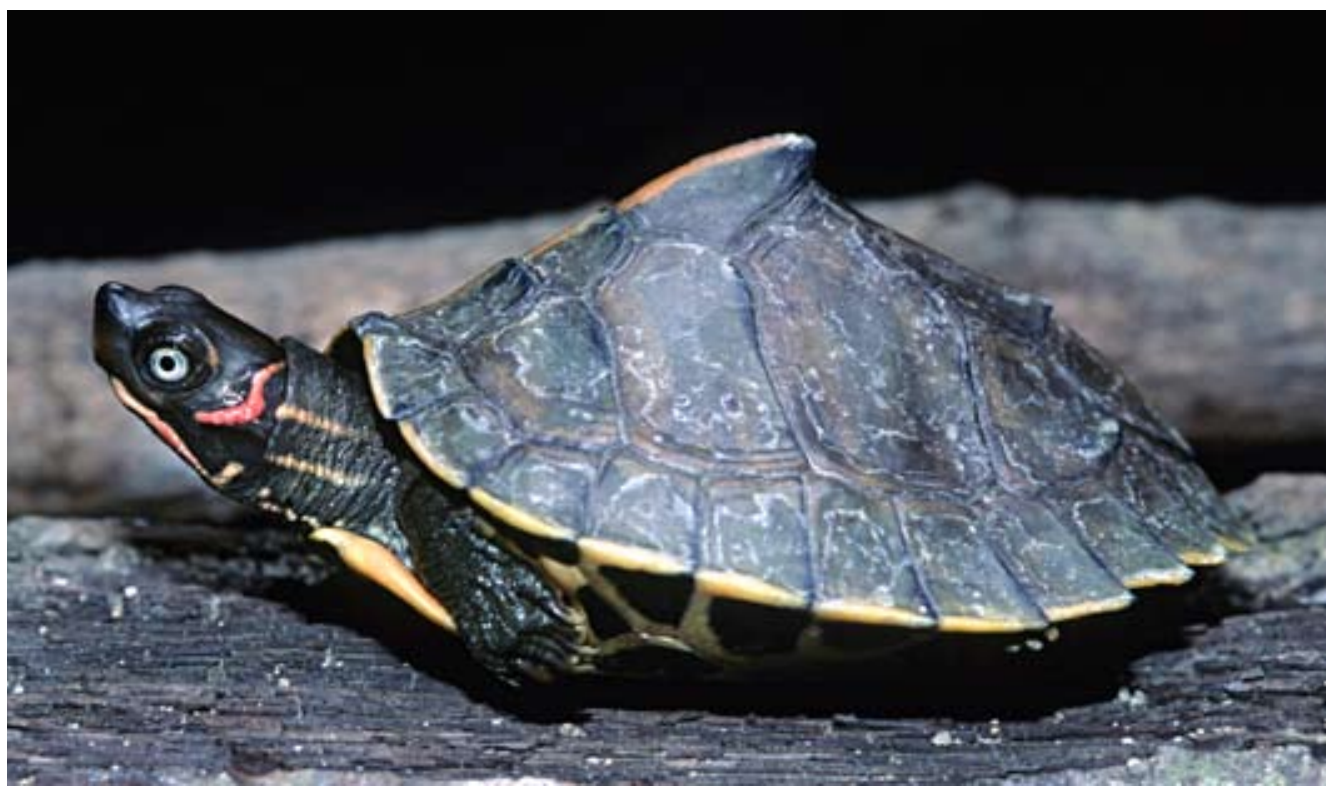

Figure 1. Adult male Pangshura sylhetensis from Kulsi River, Kamrup District, Assam, India. Photo by Indraneil Das. 


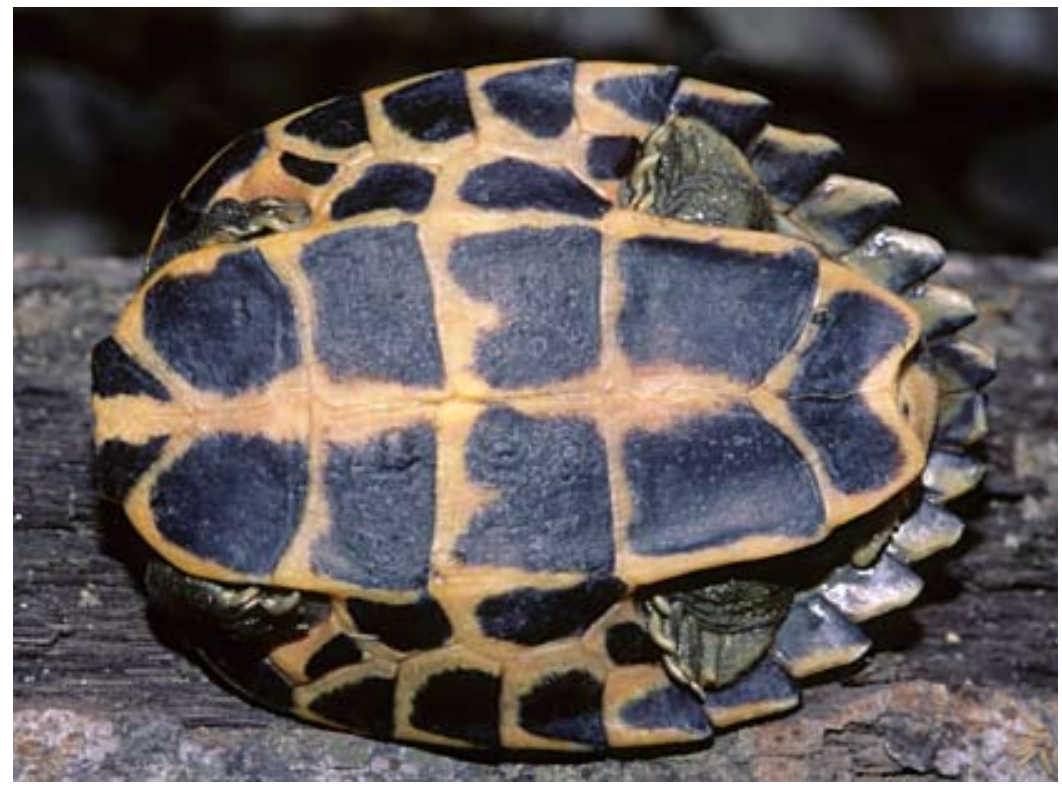

Figure 2. Adult male Pangshura sylhetensis from Kulsi River, Kamrup District, Assam, India, same as Fig. 1. Photo by Indraneil Das.

Pangshura (see Das 2002; Spinks et al. 2004). No subspecies have been described.

Description. - The carapace is markedly elevated and somewhat triangularin cross-section, with flat, sloping sides, a prominent and high spiked vertebral keel, and prominently serrated posterior marginals. In lateral profile, the upper surfaces of the first three vertebral scutes of juveniles and males form a virtually straight line, rising sharply towards the rear; in larger females the line is more rounded. The first vertebral scute is relatively short, broader anteriorly in young animals, but equally broad anteriorly and posteriorly in adults. Vertebral 2 is even shorter, but vertebral 3 is relatively long and is posteriorly elevated into a prominent posteriorly-raked vertebral spine. Vertebral 4 has a long, relatively narrow anterior extension, narrowly touching

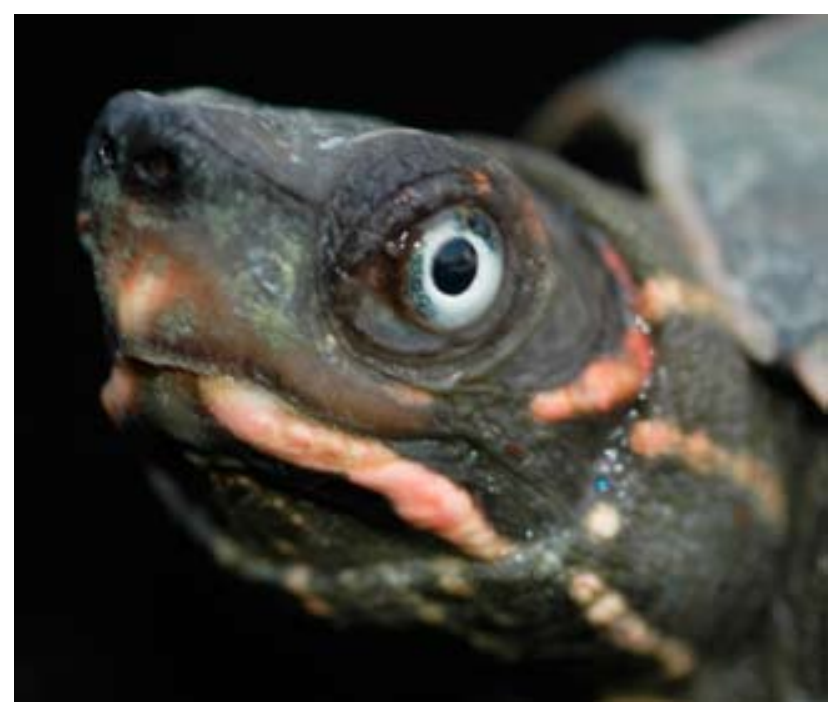

Figure 3. Head of adult male Pangshura sylhetensis from Kulsi River, Kamrup District, Assam, India, same as Fig. 1. Photo by Indraneil Das. vertebral 3, and is the longest of the series. Juveniles show a second, less prominent spine on vertebral 4 . Thirteen pairs of marginal scutes are present, a characteristic unknown in any other freshwater turtle species. The additional pair appears to be formed by division of the supracaudal scutes (Smith 1931), and has been noted in all specimens examined ( $\mathrm{n}=70$; Praschag, unpubl. data).The anterior marginals are quite short, but towards the middle of the series and extending to the supracaudals, the marginals become radially elongate.

The plastron is about as long as the carapace, laterally angulate, and anteriorly truncate. The hind lobe is smaller than the posterior shell opening, and has a strong anal notch; the length of the hind lobe is slightly less than that of the bridge. The longest midline suture is between the femorals,

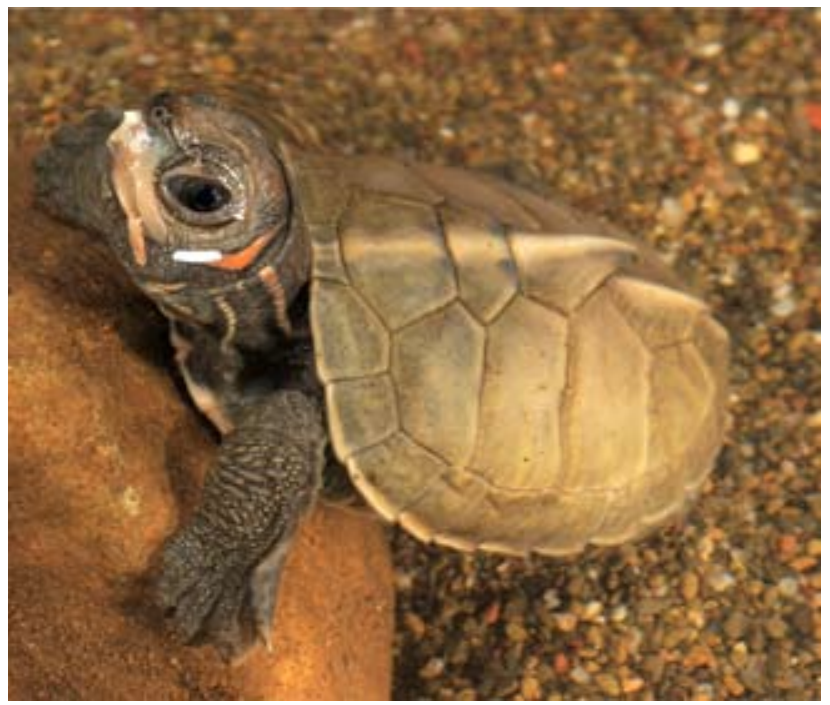

Figure 4. Hatchling Pangshura sylhetensis. Photo by Peter Praschag. 


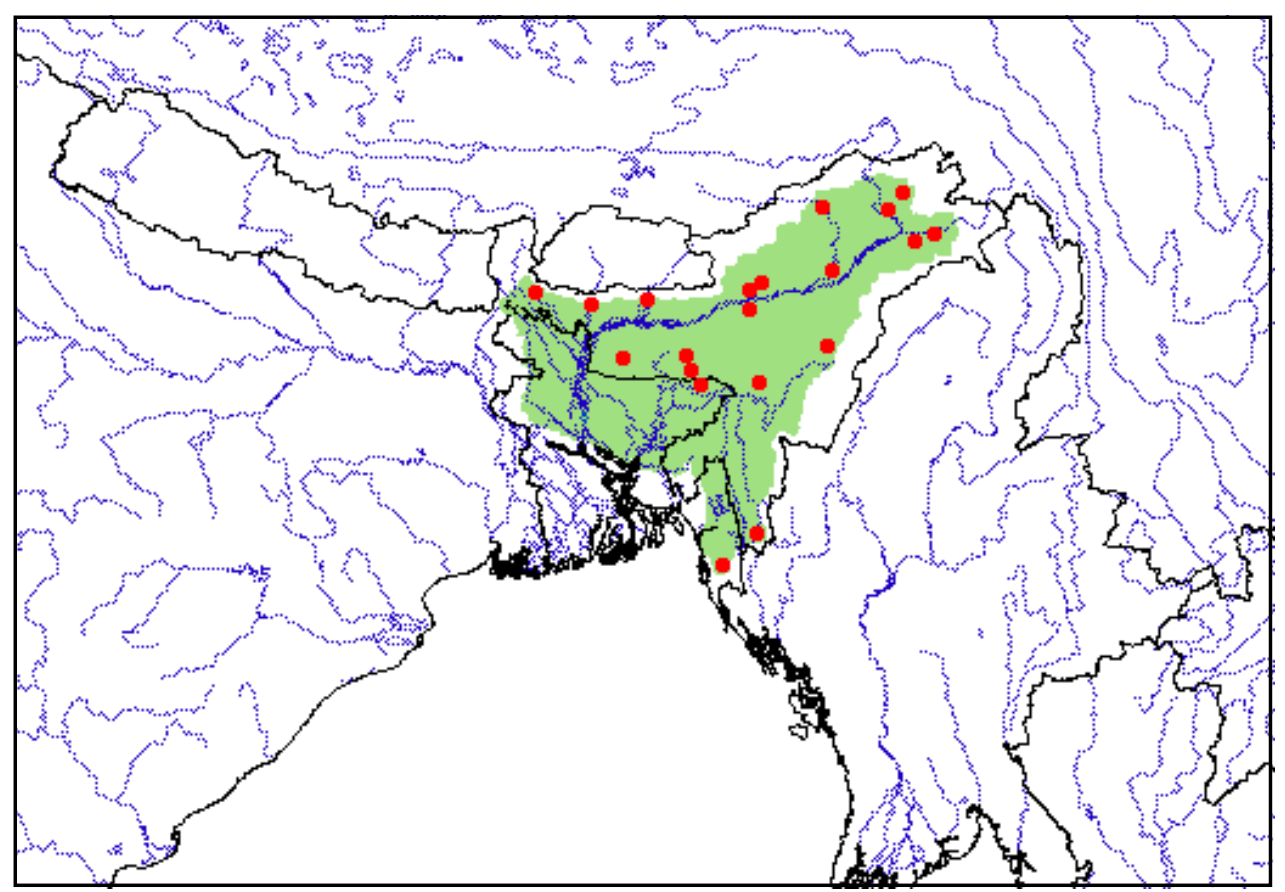

Figure 5. Distribution of Pangshura sylhetensis in India and Bangladesh. Red points = museum and literature occurrence records based on Iverson (1992) plus more recent and authors' data; green shading = projected distribution based on GIS-defined hydrologic unit compartments (HUCs) constructed around verified localities and then adding HUCs that connect known point localities in the same watershed or physiographic region, and similar habitats and elevations as verified HUCs (Buhlmann et al. 2009), and adjusted based on authors' data.

rarely between the abdominals, the shortest between the gulars. The axillary and inguinal scutes are large.

The head is small, with a slightly projecting snout, the upper jaw weakly hooked. Faint divisions are evident in the skin of the posterior part of the head. The digits are broadly webbed and the limbs bear transversely enlarged scales with 7 to 9 rows of 2 to 4 scales on the forelimbs and 5 to 7 rows of 1 to 2 scales on the hindlimbs. The lateral edge of the forelimb consists of about 10 enlarged scales, perhaps for stronger resistance in water.

The carapace is olive-brown with a pale yellowish to beige vertebral keel, which in juveniles is bright pink.
Faint streaks, slightly lighter than the ground color, may be evident on the costal and marginal scutes of juveniles and males, similar to the vermiculated pattern seen on Chitra indica. This pattern produces a camouflage effect against the light-shade pattern of sandy bottoms in clear water (Praschag and Fachbach 2001). The plastron is yellow with one brown blotch on each scute. A narrow reddishpink stripe runs from the back of each eye to the middle of the back of the head, with a second more intense pink one along the mandibles, curving up to join the tympanum, sometimes connecting with the first. The neck has ca. 9 narrow cream-yellow stripes.

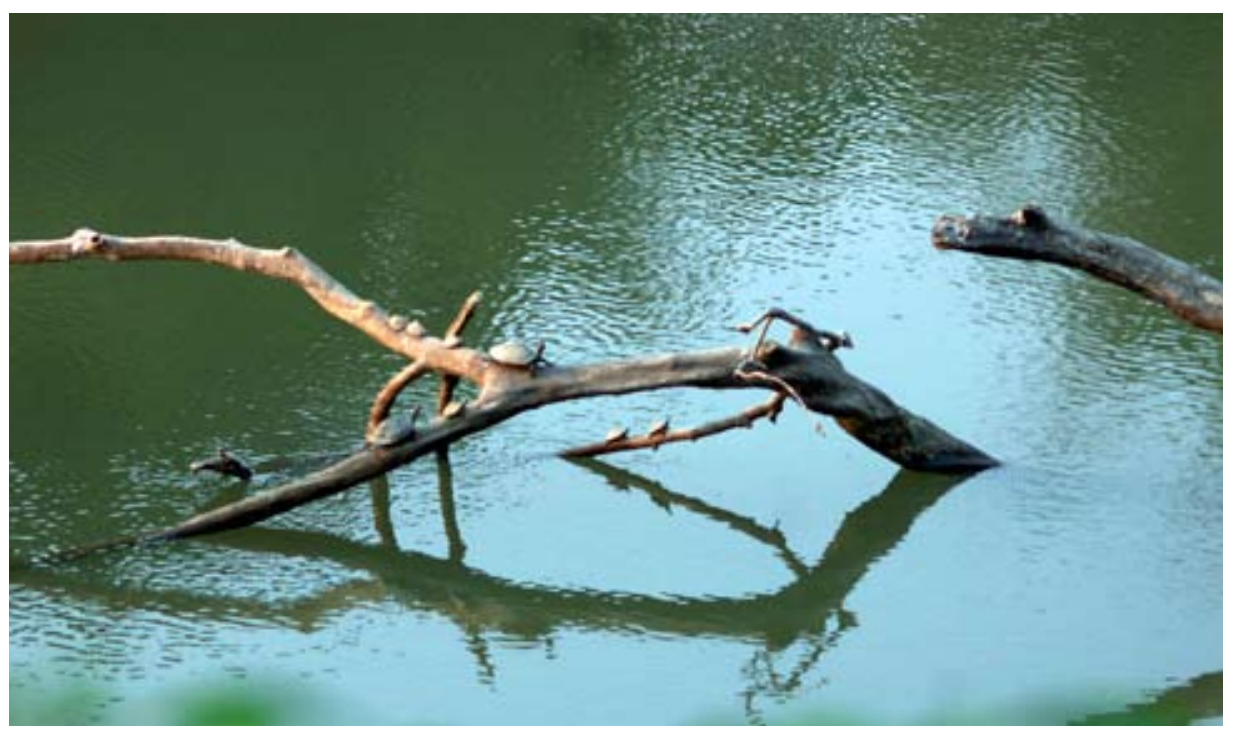

Figure 6. Basking group of Pangshura sylhetensis at Kaziranga National Park, Assam, India. Photo by Indraneil Das. 
The species is strongly sexually dimorphic, with females ca.twice as large as males. Females have been recorded up to $185 \mathrm{~mm}$ straight CL, while males are considerably smaller, only known to attain a CL of $97 \mathrm{~mm}$ (Praschag, unpubl.data). Though one of the original female syntypes was recorded by Jerdon (1870) as being $197 \mathrm{~mm} \mathrm{CL}$, the specimen itself only measures $184 \mathrm{~mm}$ CL (Praschag, unpubl. data).

The karyotype is unknown and no phylogeographic studies of P. sylhetensis have been done. Praschag et al. (2007), using mitochondrial DNA, investigated the genetic relationships of the genera Kachuga and Pangshura, including $P$. sylhetensis, and confirmed the monophyly of Pangshura. They found that $P$. smithii and P.tentoria were sister species, with $P$. tecta and $P$. sylhetensis their successive sister taxa. A more recent study revealed a sister relation with $P$. tecta, with P. smithii being sister to that group (Baruah 2010).

Distribution. - The Assam roofed turtle is distributed over northeastern India and northeastern and southeastern Bangladesh. The species was described from "Terria Ghat at the foot of the Khasi hills" (presumably in Sylhet District, Bangladesh, where several localities named Tori Ghat [= passenger country boat stations] exist). A second locality from the southeast of the country, mentioned by Das (1995), is Mainimukh, in the Chittagong Hill Tracts. Khan (1982) suspected its occurrence along the southern slopes of the Khasi and Jaintia Hills, in Sylhet District, as well as the southern ranges of the Garo Hills of Jamalpur and Mymensingh Districts.

Specific localities in India are documented by Choudhury (1993, 1995), Choudhury et al. (1999), Das (1995, 1997), Lahkar (2000), Pawar and Choudhury (2000), and Sarma et al. (2009). They include the Gorumara Wildlife Sanctuary, West Bengal, Cachar Hills, Manas Tiger Reserve, Kamrup District, Kolathua village in Sibsagar District, Nameri Wildlife Sanctuary, Ghilamara in Lakhimpur District, Kaziranga National Park, and Dibru-Saikhowa Wildlife Sanctuary, Darrang, Udalguri, and Sonitpur in Assam, Cherrapunjee and the Garo Hills in Meghalaya, Ngenpui in Mizoram, the Naga Hills of Nagaland, and Arunachal Pradesh, as well as Dirak Gate, Namsai, and Gebthu, Lohit District, in Arunachal Pradesh (Rupali Ghosh, pers. obs.).

This species appears to have one of the narrowest distributions of any south Asian geoemydid, and indeed, for about a century following its first description, it was almost unknown apart from the type series in the British Museum.

Habitat and Ecology. - The Assam roofed turtle is known from areas with upland tropical moist forest, and the general habitat of the species may be fast-flowing streams and perhaps also small rivers (Choudhury et al. 1999; Das 2002). Oxbow lakes may also be inhabited, but the gross morphology of the shell of this species is strongly suggestive of adaptation to fast-flowing waters. Nevertheless, it has been collected in low-lying marshes in the plains, and Choudhury et al. (1997) thought that such populations may have been washed downstream during monsoonal flooding. The species is known from localities on both banks of the
Brahmaputra. Sarma (1988) collected a specimen from the shallow Rupahi River (depth ca. $35 \mathrm{~cm}$ ) at Manas Tiger Reserve, Assam. Choudhury (1993) described the habitat at Ghilmara, as well as the Bonko Beel area of Dibru-Saikhowa Sanctuary, Assam, as reed beds of nal (Arundo donax), with sluggish channels on flat flood plains. Choudhury et al. (1997) reported specimens from Kukurmara River and Chandubi Beel, the former a fast flowing stream with sandy bottom and extensive growth of Ipomoea, the latter a reed bed on mud with a variety of aquatic macrophytes.

Praschag and Fachbach (2001) described the habitat of P. sylhetensis in Nameri National Park, Assam, India. The area is flooded by the dense river system of the Jia-Bhoroli, and at the peak of the dry season the water is clear with visibility up to $1.5 \mathrm{~m}$ deep and fast flowing with high oxygen content and low temperature. The river bottom consists of fine sand and round stones of various sizes - this gravel bed heats up strongly during the day with the effect that daily water temperature differences can fluctuate up to $3.5^{\circ} \mathrm{C}$. No submersed macrophytic plants were noticed in the habitat, just muskgrass (Chara sp.). The water level rises by several meters in the rainy season and the banks become flooded and provide a rich diversity of feeding plants. Juveniles, males and small females can be found in oxbows and in shallow sections of small rivers without strong current, whereas adult females occur exclusively in deeper river channels and pools of the rivers. Pangshura sylhetensis is syntopic in such habitats with the Assam leaf turtle, Cyclemys gemeli.

In Kaziranga National Park P. sylhetensis could be observed in slow moving river channels with muddy water and a variety of water plants. Here the species basks in high numbers on logs, but avoids mud banks. Pangshura sylhetensis occupies a different ecological niche than all other Pangshura species - smaller,faster-flowing, and cooler rivers are clearly preferred.

In Assam, especially in the cooler months of the dry season, from December to February, P.sylhetensis basks from $0900 \mathrm{hrs}$ to almost $1800 \mathrm{hrs}$. In the cooler hill streams the species basks year round. In contrast to all other Pangshura species, the shy $P$. sylhetensis never basks on river banks, but only on emergent logs or rocks. At the slightest disturbance, it dives quickly to the middle of the river, hiding between rocks. Juveniles often flee into accumulations of dead leaves for camouflage and remain motionless (Praschag, pers.obs.). Communal basking, involving up to a dozen individuals of both sexes are frequently observed in the smaller channels of Kaziranga National Park (Das, pers. obs.).

In strong currents $P$. sylhetensis claws into the substrate and moves jerkily from rock to rock. With the help of its claws the species also holds on firmly to logs, roots, or rocks and can even move upside down on overhanging rocks or logs, in similar fashion to the small American kinosternid turtle, Sternotherus depressus (Praschag, pers. obs.).

According to local people in Assam, the nesting season for $P$. sylhetensis occurs during the cool dry season, beginning at the end of October and lasting until February, 
with a peak in November - December and a second one in February (Praschag and Fachbach 2001). Locals also claim that clutches of 6-12 eggs are produced, averaging 8-9, and that hatchlings appear mainly between March and April, at the beginning of the Southeast Monsoons (Praschag and Fachbach 2001).

In captivity, a small female of $160 \mathrm{~mm}$ CL produced a first clutch of 6 eggs in March 2007 and a second clutch of 11 eggs in February 2008; the smallest egg measured 33.8 $\mathrm{mm} \times 21.0 \mathrm{~mm}$, the biggest $45.0 \mathrm{~mm} \times 22.5 \mathrm{~mm}$, and the average size was $39.4 \mathrm{~mm}$ x $21.1 \mathrm{~mm}$ (Praschag, unpubl. data).

The blood fluke, Coeuritrema sutlejensis (Schistosomatoidea: Spirorchidae) has been reported in the species by Tandon and Gupta (1982), and the nematode, Micropleura lissemysia (Nematoda: Micropleuridae) by Sood (1999). However, as Tandon and Gupta (1982)'s specimens came from "River Sutlej at Ropar (Punjab)," far west of the known range of $P$. sylhetensis, its identity is suspect.

Population Status. - No estimates exist. The species appears to be rare even within its limited range (Das 1991; Rashid and Khan 2000), although it appears to be locally abundant in Kaziranga National Park in Assam, India.

Threats to Survival. - The clearing of primary forests in the hills and the resultant siltation and seasonal drying up of streams potentially threatens the survival outlook of this species. Gupta (2002) reported intensive hunting of the species, including juveniles, through snaring or the use of spears. Some numbers are collected for local food consumption and the international pet trade.

Conservation Measures Taken. - The species is protected under Schedule I of the Indian Wildlife (Protection) Act of 1972, and has been classified as Endangered on the IUCN Red List since 2000. It is listed on CITES Appendix II under Pangshura spp.

The species occurs in Manas National Park, Assam, an area affected by tribal secessionist movement since the 1990s. It has also been recorded from Gorumara National Park, West Bengal (Das 1997), Kaziranga National Park, Assam (Lahkar 2000), where it appears to be fairly abundant, Dibru-Saikhoa National Park, Assam (Dwivedi 2009), Ngenpui Wildlife Sanctuary, Mizoram (Pawar and Choudhury 2000), Pakhui Wildlife Sanctuary, Arunachal Pradesh (Datta 1998), and Nameri National Park, Assam (Praschag and Fachbach (2001). Baruah et al. (2010) reported in-situ conservation efforts in Assam, involving nest collection and artificial hatching of eggs.

Conservation Measures Proposed. - More intensive surveys are needed to document population status and threats, and to locate viable populations. This is one of several turtle species that will benefit from the protection of upland evergreen forests.

Captive Husbandry. - Choudhury et al.(1997) reported that captive specimens accepted both plant matter (including fronds of Pistia, soft roots of Eichhornia, stems of Utricularia, leaves of Salvinia, fleshy parts of Trapa, the inner soft parts of Ipomoea batanus) and animals (earthworms, mollusks, aquatic insects, and prawns). Earthworms were found to be a favorite, and three to four were consumed at a time; the forelimbs were used in the manipulation of prey. Sarma (1988) reported on an individual in captivity that was shy and non-aggressive, hiding during the day, and accepting small freshwater fishes, but not plant matter. Praschag and Fachbach (2001) reported the species to be shy and nocturnal, showing intraspecific aggression. Specimens in Praschag's collection feed on dandelions, different kinds of lettuce, water cress (Rorippa nasturtium-aquaticum), and Vallisneria sp. They also feed on fish and gelatin containing snails and shrimp, as well as water snails.

Current Research. - No information. A study of the ecology and specific conservation needs of the species is required.

Acknowledgments. - Supported by the Centre for Herpetology, Madras Crocodile Bank Trust,Universiti Malaysia, Sarawak, and Arya Vidyapeeth College. We thank N.K. Choudhury for companionship during field work, Rupali Ghosh for unpublished locality records from Arunachal Pradesh, Aaron M. Bauer for a citation, and Genevieve V.A. Gee and John Iverson for reading the manuscript.

\section{LITERATURE CITED}

BARUAH,C. 2010.Applications of bioinformatics in wildlife research: a case study on turtle model. In: Goswami, U.C., Sharma, D.K., Kalita,J.and Saikia,P.K.(Eds.).Biodiversity and Human Welfare. Guwahati: Narendra Publishing House. pp. 11-18.

Baruah, C., Sarma, P.K., AND Sharma, D.K. 2010. Status and conservation of Assam roofed turtle Pangshura sylhetensis in the Brahmaputra floodplain, Assam, India. NeBio 1(3):42-47.

Boulenger, G.A. 1889. Catalogue of the Chelonians, Rhynchocephalians, and Crocodilians in the British Museum (Natural History). London: British Museum (Natural History), 311 pp.

Buhlmann, K.A., Akre, T.S.B., Iverson, J.B., Karapatakis, D., MitTERMEIER, R.A., GEORges, A., RHODIN, A.G.J., VAN DiJK, P.P., AND GibBons, J.W. 2009. A global analysis of tortoise and freshwater turtle distributions with identification of priority conservation areas. Chelonian Conservation and Biology 8(2):116-149.

Choudhury,A. 1993. New locality records for Kachuga sylhetensis (Jerdon, 1870). Hamadryad 18:43-45.

Choudhury, A. 1995. The Assam roofed turtle Kachuga sylhetensis in Sadya-a new locality record. Journal of the Bombay Natural History Society 92:426.

Choudhury, N.K., Sharma, D.K., and Sengupta, S. 1997. Notes on distribution and diet of Kachuga sylhetensis. Hamadryad 22:61-62.

Choudhury, N.K., Sharma, D.K., and Sengupta, S. 1999. Diversity and distribution of Kachuga in Kamrup District. Tigerpaper 26(1):27-29.

DAs, I. 1991. Colour Guide to the Turtles and Tortoises of the Indian Subcontinent. Portishead: R \& A Publishing Limited, 133 pp.

DAS, I. 1995. Turtles and Tortoises of India. Bombay: World Wide Fund for Nature - India/Oxford University Press, $176 \mathrm{pp}$.

DAS, I. 1997. Kachuga sylhetensis recorded from northern Bengal, with notes on turtles of Gorumara National Park, eastern India. Chelonian Conservation and Biology 2:616-617.

DAS, I. 2002.APhotographic Guide to the Snakes and Other Reptiles 
of India. London: New Holland Publishers (U.K.) Ltd., 144 pp.

DatTA, A. 1998. Records of turtles from Pakhui Wildlife Sanctuary, Arunachal Pradesh, northeast India. Journal of the Bombay Natural History Society 95:121-123.

DwIVEDI, K.K. 2009. Incredible Dibru-Saikhoa National Park. Tinsukia: Dibru-Saikhoa Conservation Society, $(10+) 151 \mathrm{pp}$.

GraY, J.E. 1870. Supplement to the Catalogue of Shield Reptiles in theCollection of the British Museum.PartI.Testudinata(tortoises). London: British Museum, 120 pp.

GuPTA, A. 2002. The beleaguered chelonians of northeastern India. Turtle and Tortoise Newsletter 6:16-17.

IVERSON,J.B. 1992.ARevised Checklist with Distribution Maps of the Turtles of the World. Richmond, IN: Privately printed, 363 pp.

JERDON, T.C. 1870. Notes on Indian herpetology. Proceedings of the Asiatic Society of Bengal 1870(3):66-85.

KHAN,M.A.R. 1982.Chelonians of Bangladesh and their conservation. Journal of the Bombay Natural History Society 79:110-116.

LAHKAR, B.P. 2000. The Assam roofed turtle Kachuga sylhetensis in Kaziranga National Park - a new locality record. Hamadryad 25:208-210.

Moll, E.O. 1986. Survey of the freshwater turtles of India. Part I: The genus Kachuga. Journal of the Bombay Natural History Society 83:538-552.

Moll, E.O. 1987. Survey of the freshwater turtles of India. Part II: The genus Kachuga. Journal of the Bombay Natural History Society 84:7-25.

PAWAR, S.S. AND CHOUdHURY, B.C. 2000. An inventory of chelonians from Mizoram, north-eastIndia: new records and someobservations on threats. Hamadryad 25:144-158.

Praschag, P. ANDFACHBACh, G.2001. Beiträg zur Kenntnis der AssamDachschildkröte, Kachuga sylhetensis (Jerdon, 1870) (Reptilia: Testudines: Bataguridae). Salamandra 37:129-148.

Praschag,P.,Hundsdörfer,A.K., AND Fritz,U.2007.Phylogeny and taxonomy of endangered South and South-east Asian freshwater turtles elucidated by mtDNA sequence variation (Testudines: Geoemydidae: Batagur, Callagur, Hardella, Kachuga, Pangshura). Zoologica Scripta 36:429-442.

RASHID, S.M.A. AND KHAN, S.M.H. 2000. Overview of turtle trade in Cambodia.In: vanDijk,P.P.,Stuart,B.L., and Rhodin,A.G.J.(Eds.). Asian Turtle Trade: Proceedings of a Workshop on Conservation and Trade in Freshwater Turtles and Tortoises in Asia. Chelonian Conservation Monographs 2:77-85.

SARMA, S.K. 1988. A new record of the Assam roofed turtle, Kachuga sylhetensis (Jerdon) from the Manas Wildlife Sanctuary, Assam. Journal of the Bombay Natural History Society 85:623-624.

Sмiтh, M.A. 1931. The Fauna of British India, including Ceylon and Burma. Reptilia and Amphibia. Vol. I. Loricata, Testudines. London: Taylor and Francis, 185 pp.

Sood, M.L. 1999. Reptilian Nematodes from South Asia. Dehradun: International Book Distributors, 299 pp.

SpinKs, P.Q., Shaffer, H.B., Iverson, J.B. AND McCord, W.P. 2004. Phylogenetic hypotheses for the turtle family Geoemydidae. Molecular Phylogenetics and Evolution 32:164-182.

TANDON, V. AND GUPTA, N.K. 1982. On some blood flukes (Spirorchiidae: Coeuritrematinae) from freshwater chelonians in India. Proceedings of the Indian Academy of Sciences: Animal Science 91:275-282.

\section{Citation Format for this Account:}

Das, I., Sengupta, S., AND Praschag, P. 2010. Pangshura sylhetensis Jerdon 1870 - Assam roofed turtle. In: Rhodin, A.G.J., Pritchard, P.C.H., van Dijk, P.P., Saumure, R.A., Buhlmann, K.A., Iverson, J.B., and Mittermeier,R.A.(Eds.). Conservation Biology of Freshwater Turtles and Tortoises: A Compilation Project of the IUCN/ SSC Tortoise and Freshwater Turtle Specialist Group. Chelonian Research Monographs No. 5, pp. 046.1-046.6, doi:10.3854/ crm.5.046.sylhetensis.v1.2010, http://www.iucn-tftsg.org/cbftt/. 